\title{
Science education goals and curriculum designs in American and Chinese High Schools
}

Article in International Review of Education - September 1995

DOI: $10.1007 / B F 01103035$

CITATIONS

3

3 authors, including:

Zhixin Su

California State University, Northridge

16 PUBLICATIONS 325 CITATIONS

SEE PROFILE
READS

57

All content following this page was uploaded by Zhixin Su on 27 November 2014. 


\title{
SCIENCE EDUCATION GOALS AND CURRICULUM DESIGNS IN AMERICAN AND CHINESE HIGH SCHOOLS
}

\author{
ZHIXIN SU, SUZANNE GOLDSTEIN and JILIN SU
}

\begin{abstract}
This paper reports findings from a comparative study of science education goals and curriculum designs in American and Chinese high schools, based on data gathered from a survey of Chinese educationists who came to the USA as visiting scholars between 1991 and 1994. The ideal goals of science education are similar in the USA and China, but the real emphases are quite different in the two nations' schools. In curriculum design, American science education has wider scope but much less depth than its Chinese counterpart. These differences are also reflected in textbooks and classroom activities. Implications for change in science education are discussed for both American and Chinese high schools.
\end{abstract}

Zusammenfassung - Dieser Artikel befaßt sich mit den Ergebnissen einer vergleichenden Studie zu den Zielen der wissenschaftlichen Erziehung und Curriculumsentwürfen in amerikanischen und chinesischen Hochschulen; basierend auf einer Studie chinesischer Erziehungswissenschaftler, die zwischen 1991 und 1994 als Gastschüler in die USA kamen. Die Idealziele wissenschaftlicher Erziehung sind in den USA and in China gleich, aber die reale Umsetzung ist in den Schulen beider Nationen sehr unterschiedlich. Im Curriculumsentwurf hat die wissenschaftliche Erziehung der Amerikaner einen breiteren Umfang aber weniger Tiefgang als die ihrer chinesisischen Kollegen. Diese Unterschiede zeigen sich auch in Textbüchern und Aktivitäten im Klassenraum. Diskutiert werden anschließend Änderungsvorschläge sowohl für amerikanische als auch für chinesische Hochschulen.

Résumé - L'article commente les résultats d'une étude comparative entre les EtatsUnis et la Chine sur les objectifs de l'enseignement scientifique et l'élaboration des programmes correspondants. Ces résultats proviennent de données collectées lors d'une enquête réalisée par des pédagogues chinois séjoumant dans des lycées américains entre 1991 et 1994. Les objectifs théoriques fixés pour !'enseignement des sciences correspondent dans les deux pays, mais les applications pratiques divergent notablement. En ce qui concerne la structure des programmes, l'enseignement américain est plus vaste mais moins approfondi que son équivalent chinois. Cette différence se reflète également dans les manuels scolaires et les activités en classe. S'ensuit une discussion sur les conséquences qu'aurait une révision de l'enseignement de cette matière dans les lycées des deux pays.

Sumario - Este trabajo informa los resultados de un estudio que compara los objetivos de la educación y los delineamientos de currículo de las universidades estadounidenses y chinas, basándose en datos recogidos de un informe confeccionade por especialistas en pedagogía chinos que permanecieron en los EE UU entre 1991 y 1994 como eruditos invitados. Si bien los objetivos ideales de los estudios científicos son similares en los EEUU y en China, los énfasis reales son bastante diferentes en los sistemas de ambas naciones. en el delineamiento del currículo americano, la educaión científica presenta una gama más amplia, pero mucho menos profunda que la de su equivalente china. Estas diferencias también se reflejan en los libros de textos 
y en las actividades en las aulas. Se están discutiendo las consecuencias para un cambio en la educación científica, tanto para universidades estadounidenses como para las chinas.

Резюме - Эта' статъя сообщает данные полученные во время сравнительного исследования целей образования в области естественных наук и проектов планов обучения в срецних школах в Америке и в Китае. собранье с обозрения китайских педагогов между 1991 и 1994 гт, приехавших в CША в роли приглашёпных учёных. Идеальные цели образования в области естественных наук очень похожи в CUIA и в Китае, ио в шхолах этих двух стран, действительно подчёркиваются совсем разиые аспекты. В проектировании планов обучения, американское образование в области естественных наук имеет более иирокий масштаб, но гораздо меньше глубины чем соответствуощее образование в Кнтае. Эти разиищы тоже отражаются в учебниках и в классных занятия. Обсуждается смысл даниых в связи с пужными переменами образования в области естественных иаук как в американских так и в китайских школах.

In 1988 Jon Miller, in an editorial in the American Scientist, estimated that only five percent of the population in the US is "scientifically literate" (p. 116). At the same time, Starver and his associates (1989) found that over policy makers. In 1990, for the first the National Governors' Association announced a set of the United States and the National were to be reached by the year 2000 . One of national goals for education that we concerns science education: "US students will be the first in the of the goals conceric science achievement" (spring, 1991). The challenge is how to close the huge gap between the established national goal and the reality in American science education.

A similar gap exists in China. Although the students participating in international assessments of math and sciences performed well, most of their peers in China are struggling to achieve basic science literacy. Many students in the rural areas do not have access to quality science education. One of the four modernization goals in China is the modernization of science and technology. This goal cannot be realized without significantly improving the existing science education in the nation's schools.

The present study has been designed as a result of the development of the "Chinese Science Educator Training Program," an international cooperative effort funded by the World Bank and coordinated by the Chinese State Education Commission and the China Institute in the California State University at Northridge (CSUN). For the academic years of 1991-92, 
1992-93, and 1993-94, the Program arranged for three groups of Chinese science education teacher educators to study in the US as visiting scholars, based on the CSUN campus. The presence of the Chinese science educators in the US provided a anique opportunity for a comparative education in both nations. To date there has been no such study, and test scores from international comparisons often fail to explain the complexity and differences in science education between and among nations.

The purpose of the present study was not to test well-formulated hypotheses or to compare students' test scores, but to explore and describe the existing strengths and weaknesses of science education in the United States and China from the first-hand experiences and reflective perceptions of Chience visiting scholars, and further to speculate implications for change in science education in both nations.

Specifically, the aims of the study were:

- To identify and compare the goals for science education in the US and China;

- To examine and compare the curriculum designs and curricular contents in science education in American and Chinese high schools;

- To explore and compare the instructional procedures - teaching methods and learning approaches - in science education in American and Chinese high schools;

- To speculate necessary changes in science education.

While the findings on science education instruction - teaching methods and learning approaches - are presented in a separate report, this paper will focus on describing and comparing science education goals and curriculum designs in American and Chinese high schools.

\section{Methodology}

The Subjects for the proposed study consisted of 41 Chinese visiting scholars in science education who participated in the "Chinese Science Educator Training Program" funded by the World Bank and sponsored by CSUN between 1991 and 1994. All of the subjects were full-time faculty members in the Chinese teacher training institutions and all had had rich experiences in science education and teacher preparation. They were able to provide the researchers with a comprehensive picture of science education in Chinese secondary schools.

None of the Chinese scholars had been to the US before. During their oneyear stay in the US, each scholar visited eight high schools including one private school in the Los Angeles area. Altogether the science teach 150 science education classes, came into contact with nearly 80 science teachers, and observed approximately 2,000 American students. They offered the present study a rich portrayal of American science education based on their 
observations, impressions, and interactions with American teachers and students. Two thirds of the Chinese scholars wrote detailed reports on their observations.

The major instrtment for the proposed study is a survey questionnaire of five parts: the first section concerns the demographic backgrounds of the subjects themselves: the second section is on science education goals; the third section addresses issues in science education curriculum; the fourth section pertains to science education instruction; and the final section concerns suggestions for reform. Most of the items in the survey were designed in openended form so as to generate unlimited responses and rich descriptions. The survey questionnaires were distributed to all visiting scholars at the end of their training programs and the response rate was $100 \%$. In addition, one-hourlong individual interviews were conducted with 19 of the scholars, and examples were drawn from the comparative education essays written by the scholars at the end of their visits.

In data management and analysis, content analysis was employed to summarize and compare the goals, the curricular contents, and the instructional procedures of science education in American and Chinese schools. The descriptions and discussions of study findings are deliberately composite and general rather than individual and particular so as to portray contrasting pictures of the most commonly occurred science education practices in both nations. The limitation of the study is that the schools visited by the Chinese scholars are typical Los Angeles area schools, and therefore are not representative of all schools in the US.

\section{Findings and discussions}

\section{Science education goals}

Stated goals and real emphases in science education

The commonly recognized and advocated goals of science education in China. as presented in the Chinese official documents and summarized by the Chinese visiting scholars, are twofold: to prepare students for higher education; and to train skilled personnel for the workplace. Accordingly the objective of science education for all students is to master the two basics - basic theories and basic skills.

Other idealistic goals for science education in China as identified by the visiting scholars in our sample include developing students' intellectual abilities, especially thinking skills and problem-solving skills, popularizing science, and promoting scientific and technological development in the nation.

The real emphases in Chinese science education, however, are quite different from the stated goals. The Chinese scholars observed that high school science education in China has been geared to the national entrance exami- 
nation for higher education. Thus it has a lopsided emphasis on learning the basic and often narrowly-focused theories of science, and it has neglected the training of basic and applicable skills for the workplace. "Getting students to pass the national examinations has been the real goal and driving force behind many science education classes in high schools," commented one science educator. Ironically, most students will never have the opportunity for higher learning because of the fierce competition and space limit, thus science education in high schools geared to higu education entrance examinations is in many ways irrelevant and inadequate for these students.

In contrast to the well-established national goals of education in China, the American schools do not share same goals. The six national goals of education established in 1990 remain largely as political slogans. Many teachers and parents are not aware of the existence of these goals. In the classroom, each individual teacher still holds on to his or her own goals and expectations. During their visits, the Chinese scholars were constantly surprised by the diversity of goals and programs in American schools. They noted that there were no common goals and requirements for all students and for most students there were no pressures for high achievements.

In the research literature, however, there is no lack of articulation of the goals and expectations for high schools science education in the US. Some bear similarities to those in China: preparation for the next level of education, and preparation for the job market (Starver et al. 1989; and Klopfer and Champagne 1990). Others expect more from science education develop habits of inquiry, compared and contrast phenomena, explore the in inferences from among living things, interpret environmentassify, and so on (Goodlad 1984). data, formulate hypotheses, obs reform project, Project 2061, also calls for all high school graduates to: understand how the scientific endeavor works - what science, math, and technology are like and how they are related to one another; science, math, and technology are like and the role of humans in it; grasp a limited
be able to view the world of nature and the
but powerful amount of knowledge about science, math, and technology in the context of history and of the cogent themes that cut across all such knowledge, and finally acquire habits of mind that prepare them to be inquisitive, critical participants of world affairs (Ogens 1991).

The American education reformers are highly critical of the reality of science education in high schools and have concluded that they are far from meeting the goals and expectations. One national study found the real emphases in American science education to be fact recall and mere possession of information (Goodlad 1984), another discovered that the traditional pattern of "assign, study, discuss, and test" pervaded most science classrooms (Starver et al. 1989).

The Chinese visiting scholars, however, were more positive in their observations. In comparison to the highly uniform classrooms and heavy emphases on basic theories and skills in Chinese science education, the American classes 
with their emphases on students' interests and individuality were very refreshing for Chinese visiting scholars. During their visits, they perceived the emphases in American science education as developing individuality, creativity, and independent thinking, and they believed thach emphases were important for all-round development of the students. What they saw as the gap between rhetoric and reality in American science education was the lack of emphases on basic theories and basic skills to the students. The American psychologist Howard Gardner made similar observations after his visits to Chinese schools: America encourages individuality but fails to teach basic skills. China teaches basic skills but fails to encourage individuality (Gardner 1989). Clearly, both cultures have much to learn from each other.

Science for all: Rhetoric and reality

American science educators have repeatedly addressed the need to create high quality science education for all students (Rutherford and Ahlgren 1990). In reality, this has not been realized. For students in the Advanced Placement (AP) classes in American schools, there is great emphasis on developing independent thinking and problem-solving abilities. There are also national standards and national examinations for AP students. They are close to meeting some of the high expectations in the reform rhetoric. The Chinese visiting scholars were very impressed by the performance of the American students attending AP classes, commenting that they were doing as well as the best Chinese students.

The Chinese visitors learned, however, only $10 \%$ of all the American high school students were in the AP and honors classes and many of the students enrolled came from fairly elite families. What access to science knowledge do the other $90 \%$ of the American high school students have? They enroll in the regular science classes or no science classes in high schools. The Chinese scholars were shocked to discover the lack of basic knowledge and skills in science subjects among these students. In one chemistry class visited by the Chinese scholars, almost no students could write down the simple ionic equations.

In general, for students in the regular science classes in American schools, the expectations and requirements are much lower, at least one or two grade lower than the common standards in Chinese schools. American students do not even have to take a single course in physics or chemistry to graduate from high schools. American science education reformers want to create highquality science education for all Americans, but it is still an ideal goal, not a reality.

Moreover, the Chinese scholars were surprised to find the poor science knowledge among many university freshman in the US. In the spring and summer of 1992, they conducted science workshops for teacher candidates at CSUN. Some of the candidates could not even solve physics problems at the Chinese elementary school and junior high school levels. The Chinese scholars 
questioned whether these candidates were qualified to become science teachers in elementary and secondary schools in the US.

In China, although there is a national syllabus and curriculum for science education, the prevalent practice of tracking places students in different tracksfast and slow classes - in science education. The students in low tracks often do not have high quality teachers and demanding learning objectives, and they have almost no hope of passing the national entrance examination for higher education. For those who intend to enter colleges and universities, there are also two tracks in the last two years of high schools - the science track and the humanities track. Students on the humanities track do not have to take more science courses, and once they enter the humanities departments in colleges and universities, most will not be required to take science courses. So far there has been no study to examine the science literacy level of these graduates. However, it is common knowledge that the lack of science knowledge among people other than specially trained scientists is detrimental to the modernization movement in China.

In addition, rural schools usually cannot provide high quality science education to students because of the lack of resources and qualified teachers. The Chinese scholars noted that some rural schools did not even have basic lab facilities. Since over $70 \%$ of the Chinese population reside in the rural areas, there is an urgent need to improve rural school conditions so as to provide equal educational opportunities to the children there. China cannot modernize its science and technology if the majority of its population are science illiterate, no matter how well the city school students perform in international science competitions.

\section{Science education curriculum}

Scope of science curriculum

The Chinese scholars discovered that the American science education curriculum covers a much wider spectrum than the Chinese curriculum. While the major subjects in science education in China's high schools are still the classic areas of physics, chemistry, and biology, the American curriculum has expanded far beyond these areas to include life science, earth science, information science, computer science, environmental science, health science, oceanography, astronomy, meteorology, physiology, genetics, geology, zoology, geography, and ecology.

Each subject is an independent curricular area in Chinese education, but the American curriculum is theme-oriented and interdisciplinary in nature. One Chinese scholar observed:

In Chinese high school science education, when you teach one science subject physics, or chemistry or biology, you teach that subject only and never mention other science subjects and problems in your classes. You are never encouraged to use interdisciplinary approaches, and never teach two different science subjects at the same time in the same room. 
In American high schools science education, however, there are no clear borderlines among different science subjects. Some science lab activities are actually integrations of experiments from physics, chemistry and biology. I believe we can learn from this interdisciplinary approach. In natural science, many to use the interdisci belong to more than one science category. It is oth in theory and in practice. plinary approach to teach and learn scie

Traditionally, science education courses in American high schools were also bounded by a concept of discrete disciplines. They went through an identity change and became more connected and interdisciplinary as a result of the belief that the simple division of school science into discrete subjects no longer has meaning in modern science (Hurd 1986). Some international scholars have made the claim that if physics, chemistry and biology are taught compulsorily and separately in secondary schools, as is the case in China, the students learn most while the layer-cake approach of the US was the worst approach in terms of achievement (Postlethwaite and Wiley 1992). Nevertheless, American high schools continue to use the layer-cake approach. American students study different science subjects together and study information in thematic blocks (Culotta 1990). Although the Chinese science education curriculum has not been influenced by this trend, the visiting Chinese scholars were clearly interested in introducing the approach to Chinese educators.

Also at issue is how well the science curriculum has been expanded to include newly developed and discovered knowledge or controversial theories in science. The Chinese scholars in our sample found that For example, whe curriculum is more conservative than the American one. Por exple, while the plate tectonics theory has been widely introduced in earth science classes in American high schools, the Chinese textbooks do not contain this topic. Most Chinese science teachers and even university professors refuse to teach it in their classes.

\section{Depth of curriculum}

Furthermore, the Chinese scholars observed a very important difference in the organization of science curriculum in high schools between the US and China. Table 1 and Table 2 illustrate this difference.

The majority of the American students follow Pattern 1 and only the students in honors and AP classes experience Pattern 2. In China, all high school students follow the same curricular pattern until the 11th grade. In the last two years in high schools, those who intend to major in non-science areas in higher education are not required to take any more science courses (they follow Pattern 2 in Table 2). Instead, they take additional courses in their areas of interest (e.g., literature, history, politics, etc.).

As clearly indicated by the tables, the average Chinese student spends twice as much time studying biology and chemistry and more than three times as much time studying physics as his or her American counterpart. This is the general impression of the Chinese visiting scholars. It is consistent with 
Table 1. Common patterns of science curriculum in the US.

\begin{tabular}{lll}
\hline Grade & Pattern 1 & Pattern 2 \\
\hline $1-6$ & Eleméntary School Science (2)* & \\
7 & Life science (5) & General Science (5) \\
8 & Earth and Space (5) & General Science (5) \\
9 & Physical Science (5) & Earth Science/Biology (5) \\
10 & Biology I (5) & Chemistry I (5) \\
$11^{* *}$ & Chemistry I (5) & Physics I (5) \\
$12^{* *}$ & Physics I (5) & Advanced Placement: \\
& & Biology (5) \\
& & Chemistry (5)
\end{tabular}

* The number in parenthesis indicates class hours per week.

* At these grade levels, students can choose not to take any science class.

Source: Jacobson et al. 1991 and survey data from the present study.

Table 2. Common patterns of science curriculum in China.

\begin{tabular}{|c|c|c|}
\hline Grade & Pattern 1 & Pattern 2 \\
\hline $1-6$ & Elementary School Nature $(2)^{*}$ & Biology (2) \\
\hline $\begin{array}{l}7 \\
8\end{array}$ & $\begin{array}{l}\text { Biology (2) } \\
\text { Biology (2), Physics (2) }\end{array}$ & Biology (2), Physics (2) \\
\hline & Chemistry (3) & $\begin{array}{l}\text { Chemistry (3) } \\
\text { Physics (3), Chemistry (3) }\end{array}$ \\
\hline $\begin{array}{r}9 \\
10\end{array}$ & $\begin{array}{l}\text { Physics (3), Chemistry (3) } \\
\text { Physics (3), Chemistry (3), }\end{array}$ & Physics (3), Chemistry (3), \\
\hline & $\begin{array}{l}\text { Biology (3) } \\
\text { Physics (3). Chemistry (3), }\end{array}$ & Biology (3) \\
\hline 11 & $\begin{array}{l}\text { Physics (3), Chemistry (3), } \\
\text { Biology (3) }\end{array}$ & \\
\hline 12 & $\begin{array}{l}\text { Physics (3), Chemistry (3), } \\
\text { Biology (3) }\end{array}$ & \\
\hline
\end{tabular}

Source: Survey Data of the Present Study

findings from a study by the American National Science Teachers Association, which found that Chinese secondary school students spend four years and a total of 256 hours studying biology, four years and a total of 372 hours studying chemistry, and five years and a total of 500 hours studying physics, whereas American secondary school students spend only one year and a total of 180 hours studying biology, one year and a total of 180 hours studying chemistry, and one year and a total of 180 hours studying physics (California Science Curriculum Framework and Criteria Committee, 1990).

Apparently, in Chinese high schools, a few basic, separate science subjects - physics, chemistry and biology - are studied simultaneously in each year, 
while in American high schools, only one science subject is studied each year. with the exception of AP curriculum for selected few 12th graders.

In addition, the Chinese scholars observe that the Chinese science curriculum is uniform, nartow, and deep, while the American curriculum is varied, broad, and flat. The Chinese curriculum is vertical and spiral in nature - the rials at different levels of schooling, with greater knowledge and deeper understandings at the higher levels. The American curriculum, on the othe levels is flat and broad in nature - it covers different areas achnology with real-life

The Chinese curriculum have common requirements for all high school istry, and 8 credits of chemistry, and 12 credits of biology (one credit equals one instruction hour per week in a semester). Under these requirements, the Chinese students are led to build their science knowledge block by block on a continuous, spiral ladder. However, not all school-age teenagers attend senior high schools. Many end their formal education after junior high schools, and some take vocational training in special classes or special schools. In addition, among all those attending high schools, only the ones in key schools or key classes in ordinary schools have access to high-quality science teachers, learning materials, and lab facilities.

The American science curriculum does not have common requirements for all students, although the state departments of education provide some general framework for schools. Individual schools and teachers decide how much and what science education students should receive. The Chinese scholars were surprised to see the many differention is consistent with the riculum in different classrooms. Their obser bacobson and his associates: description of American science curom, the science taught and the way it is "Not surpringly, within any classroom, the individual teacher believes, knows. taught is dependent primarily and does" (Jacobson et al. 1991).

The Chinese visiting scholars further discovered that the science courses offered by American junior high schools are very general and introductory, with the depth of knowledge equaling that of elementary school nature curriculum in China. Thus by the time students enter high schools, they do not have a solid foundation of science knowledge. On the other hand, the science curriculum offered at the American senior high schools are often very difficult for most students because they are not coording oach subject. To cope with and theoretical, and there is not American high school students choose to take the situation, the majority of the Ame managed to graduate from high schools a minimum of science and somistry or physics. The IEA Study of Science without any knowledge of chemistry or physi 12 th graders studying biology,
found the estimated percentages of American 
chemistry, and physics to be twelve, two, and one respectively (Postlethwaite and Wiley 1992). Nationally, only about 20 percent of graduating seniors have taken physics, while in California only 13 percent have taken physics (California Science Curriculum Framework and Criteria Committee, 1990).

While Chinese students begin to study chemistry at 8 th grade, American students do not take chemistry until the 10th or 11 th grade. Moreover, American students do not have to take physics courses until the 12 th grade. A Chinese chemistry education curriculum specialist claimed that modern chemistry is built on modern physics. He questions how Ane Chinese students can learn chemistry without the knowledge of physics. The Che the chemistry begin to learn physics at the 8th grade, at the sal learning of sciences begin at the college level. Ironically, the Chinese scholars were surprised to find that while many universities are busy offering remedial, high-school level science courses to the freshman, American high school AP classes are busy offering college level science materials to the less than $10 \%$ of the high school students. There is no equality in science education for all.

Textbooks The differences in scope and depth in the science education curriculum between the US and China are aiso reflected in the textbooks. In China, the State Education Commission has a Textbook Committee, which regulates the compilation, publication, and distribution of the textbooks. The writing, editing and compiling of the textbooks are usually collective effors, which tend to lack individual style and uniqueness. There is a systemachers and students to and deeper and deeper understanding of the basic science concepts. However, this emphasis is also narrow and rigid, with insufficient hands-on experiences and limited exposure to knowledge regarding modern science and technology.

The design and layout of the Chinese textbooks is not lively and attractive, as one Chinese scholar described it, "just like someone with a long and cold face." Almost unanimously, our subjects comment that the Chinese students do not enjoy reading their science textbooks do not encourage students to that the rigidity and uniformity of the text for students to doubt or question. think for themselves. There is no res in training science teachers in China, Drawing from their rich experiencerve that classroom teaching and learning the respondents under the stud the textbooks. As a result, they conclude, the in China depend heavily ome highly proficient in doing exercises from textbooks and in taking examinations, but they do not know how to apply theory in practice and how to connect what they learn in the schools with the reality in the workplace. In contrast to the uniform, tightly-knit, narrowly focused and "cold-faced" 
Chinese textbooks, the American textbooks for science education are diversified, loosely structured, broad in coverage and "warm-faced," the Chinese scholars observed. The students are attracted to the textbooks because of the many colorful pictures, lively introductions to new science and technology, strong connections with real life situation, interesting questions, and helpful directions for hands-on activities. The Chinese scholars were especially impressed by the strong connection between chemistry and the American textbooks. One chemistry scholar observed:

On my visit to American high schools, I saw a set of chemistry textbooks that effectively integrated the learning of chemistry with the understanding of important social issues. In China, the science textbooks do between the school and the I believe that curriculum must help close This kind of curriculum can help students society, and meet the needs of the socing the science knowledge they leam in schools.

This scholar actually conducted a small survey among nearly 100 American high school students and compared the data with that she gathered from over 300 Chinese high school students. She found that regarding the awareness of social issues as a result of taking science courses, the American students demonstrated much greater understanding than their Chince curriculum, textvisiting scholar attributed this effect to the a lot of emphasis on social issues.

The American science textbooks are also more pragmatic than Chinese textbooks, according to the Chinese visiting scholars. The Chinese science textbooks contain largely detailed presentations of theories that will be tested in the national university entrance examination. The American textbooks, on the other hand, address some real life issues for the studonolars, there are special learn that they can become occupational safety chemist, environmental chemist, research chemist, chemical sales representative, physician, chemical engineering, agricultural chemist, chemistry teacher, nurse, food scientist, materials in science education. But at least they know the possible career options in a science field.

Although there are some excellent textbooks for high school science education in the US, the Chinese scholars heard many complaints from both teachers and students that the textbooks were too difficult for the students. One major reason is the lack of structured lectures and explanations of textbook materials in classes. American teachers favor inductive mo handsinstruction and devote much of the class time to demonst the struggle with the textbooks by theives. on activities. Students are lack systematic science learning at the lower level Another roling - the students simply do not have the foundation knowledge to the students simply do 
understand the more difficult and advanced materials. The Chinese visiting scholars observed that the goals and contents of some of the science textbooks for American high schools mismatched the ability of the majority of the students in high schools. Earlier, American science education researchers also identified this problem. When they examined the readability of high school textbooks, they found that only $8 \%$ of the students were successful when attempting to read texts (Koballa et al. 1990).

The American teachers and students do not have to teach and learn according to certain textbooks required by a central administration, as is the case in China. The teachers have the autonomy to select textbooks and furthermore to select materials from the textbooks to teach in the classroom. The Chinese scholars noted that even for one grade level, there were as many as five or six different types of textbooks for American teachers to choose from. While this practice has brought into full play some teachers' initiatives and creativity, as has been demonstrated by teachers in honors and AP classes, those teachers who want to take an easy route can settle for the most mediocre of textbooks and teaching materials. Consequently, some students have access to high-quality and rich science information, while others are exposed to lowquality and minimal science materials.

This observation is contrary to findings from some American studies, which claims that since 90 to 95 percent of the teachers use textbooks as a major educational resource 90 percent of the time, there is a tendency toward homogeneity in the experiences students have in the US (Jacobson et al. 1991). Textbook may still be the most significant factor shaping course content, mode of instruction and evaluation in American science education (Hof wolt 1989). But according to the Chinese visiting scholars, American teachers were much less dependent on textbooks than their Chinese counterparts and many created their own demonstrations and experiments. Consequently, the American students can have highly varied experiences in science learning depending on the teachers they have, the courses they take, and the materials and methods they are exposed to.

In comparing the American and Chinese science education curriculum, the Chinese visiting scholars concluded that there needed to be a balance between unity and diversity in curriculum designs for both American and Chinese schools. They pointed out that the unified syllabus, curriculum designs, and textbooks in China were not suitable for all the students in different parts of the country. Currently, under the direction of common goals, Chinese science educators have begun to develop a variety of different curricula and textbooks: one set for use in the ordinary schools in most of the regions; one set for use in key schools in more developed areas; one set for use in schools in the rural and economically backward regions; and finally, one set for use in schools in minority nationality autonomous regions. In doing this, however, there is the danger of creating an educated elite and more inequality of educational opportunities for children in the less developed areas, which already exists to some extent in China. 
Closing the gap between rhetoric and reality

Both Chinese and American science education reformers want to create highquality science education for all students, but it is still an ideal goal, not a reality in both nations. In the US, only a very small slice of the student population - perhaps less than $10 \%$ - are exposed to high-quaty science knowledge in honors and AP classes. The majority high schools without even mediocre science programs and many graduate flthough there is a national goal taking a single physics or chemistry course Alt first in the world in math and which aims at making Ame are no established national standards and basic requirements for all students. In November 1994, the American National Research Council produced a draft report, National Science Education Standards, which aims at developing a set of criteria to judge the quality of what students know in science and a vision for what science education should be like (National Research Council 1994). How well the draft report will be accepted and implemented in the US is still a question.

Among the American students and teachers encountered by Chinese visiting scholars, there is a lack of clear and shared goals, and a lack of motivation and efforts to achieve in science education. As one of our Ards and requirements points out, "When there are no national or sthe students, they do not have in science education, which to learn sciences and they often choose the path the incentive and motivation of least resistence - the eanal organization to establish national standards and assessment tools. As Rutherford and Ahlgren point out, to significantly improve American science education, "what is required is national commitment, determination, and willingness to work together toward common goals" (Rutherford and Ahlgren 1990).

In China, although there are common goals and basic requirements in science education for all high school students, not all high school-age teenagers attend high schools. sures to achieve and the real purpose of science education.

The Chinese scholars were impressed by the American science education's emphasis on developing students' independent and critical thinking, individuality and creativity. In China, these elements have never been included in the educational goals. In fact, in Chinese schools, developing individuality is considered as undesirable, independent thinking is to common standards creativity is often stifled by the pressurional reform movement in China, it and performances. In the curent educatucation be expanded to include the has been suggested that the gols of enty, and independent thinking. Schools in development of individuality, creativity, and independent hinking. Schools in 
the "Shanghai 2000" - an educational reform project - are leading the nation in this reform (Shanghai Curriculum Reform Committee 1989).

Improving science, education curriculum

The Chinese visiting scholars concluded that on the average, Chinese high school science education provides students with more knowledge than American curriculum does, and the Chinese curriculum is more difficult and challenging than the American one. However, there are many problems in the existing science education curriculum in China. The following reform measures were proposed by the Chinese scholars for improving China's high school science education curriculum:

- expand the scope of curriculum and update knowledge in science textbooks to include a) new materials regarding the discovery of new theories and the development of modern science and technology; b) interdisciplinary subjects; c) interesting real-life examples; and d) related, current social issues;

- experiment with different kinds of teaching materials, including science education textbooks from other nations;

- encourage students to use scientific methods to think, to doubt, to explore and to solve problems by themselves;

- create opportunities for students to participate in creative scientific experiments (for example, organize a science fair);

- cultivate the development of individuality and individual potentials in the process of learning science;

- allow schools, teachers and students more freedom in choosing their teaching and learning materials;

- reduce the level of difficulty and amount of requirements for students so that the curriculum is a healthy load for the majority of students;

- increase hands-on experiences and extra-curricular activities related to science education;

- establish general science courses at the junior high level and elective science courses at the senior high level;

- create vocation oriented science courses to offer real job skills to students.

The visiting scholars recognized, however, that these measures can only be implemented after a fundamental reform of the nation's centralized planning system and the national university entrance examinations. Until then, teachers will be afraid to experiment, and students will be hesitant to participate in new ventures, for fear that they cannot pass the national examinations. For example, as long as scientific experiments is not a experience in their science education curriculum.

In American science education, much effort has been centered on writing textbooks, with little or no attention paid to the development of a science 
curriculum (Starver et al. 1989). For improving the science education curriculum in American high schools, the Chinese scholars offered the following suggestions: suggestions:
- establish clear goáls and high, common standards and requirements for all
students, not just for students in honors and AP classes;
-

- develop a spiral curriculum and thus a steady accumulation of science knowledge for students;

- place emphases on the systematic teaching and learning of basic concepts and skills in math and sciences;

- create a continum and systematic structure in science education;

- increase the time spent on teaching and learning basic science subjects while reducing the level of difficulty of some science curriculum and textbooks;

- establish compulsary science courses in major science subjects for all students and reduce the electives in science education so that all students have access to high-quality science knowledge;

- create national assessment criterion and instruments.

The Chinese visiting scholars were worried that their recommendations to establish common goals and national standards might not be well received by their American colleagues, who are used to andards (even though the US ualism and detests confor to create national assessments for at least some government is They were confident, however, that the other suggestions would subject areas). The American science educators, who, in recent years, have also been eager to design a spiral high school science curriculum that revisits all the concepts and provides further experience with processes introduced in the lower level schools. Such a curriculum will help students achieve a much greater degree of understanding and perfork and Criteria Committee 1990). (California Science Curricul science educators are also advocating establishing In fact, some American science curriculum for all students. There is already a model in the US, as illustrated by Herr:

The College Board's Advanced Placement Program has acted as a substitute for a national science curriculum in that it engenders a high degree of uniformity among participating schools. While the College Board is not a federal agengests possible not fund AP courses, it publishes recoms for teachers and offers national examinatextbooks, presents training workshops for teall of which are common in a nation-

tions to test mastery of the subject inal, p. 14)

Since only a small percentage of American students take the AP program, it will be a challenge to change all other programs to conform to the high standards. But the success of AP programs demonstrate that the challenge can be 
taken and the goals can be achieved if teachers and students put their hearts and minds to it.

The Chinese scholars' call to increase the time for teaching and learning basic science subjects in high schools has been echoed by some American science educators. In 1990, the California Science Curriculum Framework and Criteria Committee proposed to increase the total hours on learning biology, chemistry and physics to 288,288 , and 288 respectively for grades 7 through 12. Even when this reform plan is implemented, the Chinese high school students still spend about 100 more hours learning chemistry and 200 more hours learning physics than American high school students. The American students have a long way to go before they can become number one in science achievements in the world.

In the end, whether Chinese or American students can become number one or number two in international science competition is much less important than whether or not they can become citizens who understand science in multidimensional, multidisciplinary ways that will enable them to participate intelligently in critical thinking, problem solving and decision making about how science and technology are used to change society, a goal eloquently how science and technology are uscation reformers (Olgens 1991). The latter
articulated by American science educald be the ultimate goal for science education in both the US and China.
should

\section{References}

California Science Curriculum Framework and Criteria Committee. 1990. Science Framework for California Public Schools. Sacramento, CA: California State Department of Education.

Culotta, Elizabeth. 1990. Can Science Education Be Saved? Science 250: 1327-30.

Gardner, Howard. 1989. To Open Minds. New York: Basic Books.

Goodlad, John I. 1984. A Place Called School. New York: McGraw-Hill.

Herr, Norman E. 1992. National Curricula for Advanced Science Classes in American High Schools? The Influence of the College Board's Advanced Placement Program on Science Curriculua. International Journal of Science Education: 14-20.

Hofwolt, C. 1989. Instructional Strategies in the Classroom. In: D. Holdskom and P. Lutz, eds., Research Within Reach: Science Education. Washtington D.C.: National Science Teachers Association.

Hurd, Paul. 1986. Perspectives for the Reform of Science Education. Phi Delta Kappan 67: 353-58.

Jacobson, W., Doran, R. and Miller, J. 1991. United States. In M. J. Rosier and J. P. Keeves, eds.: 261-70.

Klopfer, L. E. and Champagne, A. B. 1990. Ghosts of Crisis Past. Science Education 74: 133-54.

Koballa, T., Crawley, F. and Shrigley, R. 1990. A Summary of Research in Science Education - 1988. Science Education 74: 253-407. 
Miller, Jon D. 1988. The Five Percent Problem. American Scientist (March/April), p. 116.

National Research Council. 1994. National Science Education Standards. Washington, D.C.: National Academy Press.

Ogen, E. 1991. A Review of Science Education: Past Failures, Future Hopes. American Biology Teacher 53: 199-203.

Postlethwaite, T. N. and Wiley, D. E. (eds.). 1992. The IEA Study of Science II: Science Education and Curricula in Twenty-Three Countries. New York: Pergamon Press.

Rutherford, F. J. and Ahlgren, a. 1990. Science for All Americans. Oxford: Oxford University Press.

Shanghai Curriculum Reform Committee. 1989. Shanghai 2000: An Education Reform Plan. Shanghai, China: Shanghai Education Bureau.

Spring, Joel. 1991. American Education. New York: Longman.

Starver, J., Enoch, L, and Associates. 1989. A Summary of Research in Science Education - 1987. Science Education 73: 243-65. 